DOI: $10.15503 /$ jecs20162.408.423

\title{
ATTRACTING PUPILS AND STUDENTS \\ TO NATURAL SCIENCES: CHALLENGES \\ IN HIGHER EDUCATION ON THE EXAMPLE \\ OF SCIENCE LEARNING CENTRE BIOSKOP \\ MASARYK UNIVERSITY \\ (BRNO, THE CZECH REPUBLIC) \\ ONDŘEJ KONEČNÝ

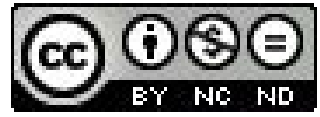

Mendel University in Brno, Faculty of Regional Development and International Studies, Department of Regional Development and Public Administration, Tř. Gen. Píky, 9, 613 00, Brno, the Czech Republic

E-mail address: ondrej.konecny@mendelu.cz

\section{ALENA PODHORNÁ}

Mendel University in Brno, Faculty of Regional Development and International Studies, Tř. Gen. Píky, 9, 613 00, Brno, the Czech Republic

E-mail address: 52633@node.mendelu.cz

\section{TEREZA HLAVÁČKOVÁ}

Mendel University in Brno, Faculty of Regional Development and International Studies, Tř. Gen. Píky, 9, 613 00, Brno, the Czech Republic

E-mail address: 42955@node.mendelu.cz

\section{PETR NOVÁK}

Mendel University in Brno, Faculty of Regional Development and International Studies, Department of Language and Cultural Studies, Tř. Gen. Píky,

9, 613 00, Brno, the Czech Republic

E-mail address: petr.novak.ujks@mendelu.cz

\begin{abstract}
Many universities in the Czech Republic lack students' interest in the studies of natural science. That is why all the universities have to come up with an idea how to popularize these scientific fields to attract potential university applicants. One of the ways of achieving that is to create educational centres, which are able, thanks to these programmes, to approach students of primary and secondary schools and show them the natural sciences. The presented example of one particular educational centre (Bioskop Masaryk University, Brno, the Czech Republic) evaluates
\end{abstract}


the success rate of their activities while using written questionnaire survey among the visitors of the programmes (students of primary and secondary schools as well as their pedagogues). The results have shown that thanks to these activities the centre created quality conditions for popularization of natural sciences. The results have also proven the centre's ability to present natural sciences in an attractive and entertaining way to students of elementary and secondary schools. These students expressed their interest in the study of natural sciences and they would like to visit the centre again.

Key words: University, Natural Sciences, Popularisation of Science, Science Learning Centre, Employment.

\section{INTRODUCTION}

Today's world is rapidly changing. It is not surprising that science and research ( $\mathrm{S}$ and $\mathrm{R}$ ) have become crucial elements to the economic growth, sustainable development and life quality improvement in every particular state. Therefore, science and research is in many countries a priority field which represents a foundation of the economy based on knowledge and innovation. Scientific and research findings and their transfer speed together with knowledge have become key sources of world economic competitiveness. Due to the fact that the results of working in the field of $S$ and $R$ have a high added value, they are often adequately awarded. This allows the $S$ and $\mathrm{R}$ employees to get higher wages and to contribute to the high living standards of a region or a country.

The technology development brings considerable changes which are laid on the labour force. As a matter of fact, the progressive sectors which need qualified workers from natural and technological fields are taking the lead. An adequate number of people with specialist education represent a local condition for the arrival of potential international investors. Universities, or research and development centres, not only play an irreplaceable role in the areas of human resources preparation and research and development, but also increase the possibilities of employment in scientific disciplines. It is becoming apparent that the fundamental problem keeping the research and development centres from larger expansion lies in the lack of experienced and talented workers rather than in the investment resources.

Current university preparation of potential workers in $S$ and $R$ is faced with a range of problems. Even though the demand for specialists in this area is growing, they are in short supply because the students applying for universities do not show interest in the subject and are more likely to choose the humanities or economics. Recent trends in Czech higher education system indicate this problem. Thus, the society and higher education in the Czech Republic were confronted with the challenge to stop this opposing trend. One of the possible instruments is the popularization of science which has been promoted through the scientific and educational centres that try to introduce students to attractive subjects of scientific activities in an entertaining way. It 
is necessary to awaken students' interest in science and the stated branches so that the centres achieve desired results. The centres should appeal not only to secondary school students but also to primary school pupils because their interests are just starting to form and we can help them with the decision which secondary school or university to choose later on.

The presented contribution addresses this particular issue. It deals with the popularization of science as a tool for more effective harmonization between supply and demand on the labour market using an actual scientific teaching centre of Masaryk University (MU) - Bioskop (Brno, the Czech Republic), which popularizes science and research, or more precisely university education in natural sciences. The main aim of the contribution is to reveal the feasibility of the above mentioned expectations and evaluate the activities of the centre in question. The information was collected by way of written questionnaire completed by primary and secondary school pupils ( $1^{\text {st }}$ group) and their pedagogical escort $\left(2^{\text {nd }}\right.$ group). The data collection was carried out in close cooperation with the educational centre.

\section{THEORETICAL ANCHORS: FROM THE SUPPORT OF SCIENCE AND RESEARCH TO THE NEED FOR POPULARIZATION OF NATURAL SCIENCES IN THE CZECH REPUBLIC}

Scientific and research centres have become an integral part of an approach to science which plays a key role in modern society. The highest form of human cognitive activities and the continuous process of systematic rational discoveries of nature, society and thinking are closely related to research (CSO, 2007; Noruzi, 2008). According to David W. Pearce (1993, p. 84), research focuses on increase of scientific and technological knowledge, as well as on its application during the development of new products and production methods, evenly oriented to improvements of existing products and production processes.

Advanced economies have been going through structural transformation since the beginning of the 70's of the twentieth century, shifting from industrial to knowledge-based economy in which scientific and research outcomes, i.e. knowledge and innovations, form the main source of wealth (Powell, \& Snellman, 2004; Vavrečková, 2007). For that reason, the support of science and research is crucial to the competitiveness of regions. For instance, the EU has been supporting investments in research and development, reforms of research and innovations, modernization of education or closer collaboration between science and the business sector for a long time. In the case of investment the target $3 \%$ GDP of EU into research and development, this should bring 3.7 million job vacancies (Vavrečková, 2007).

For such a small country as the Czech Republic with an industrial tradition but without any significant resource materials, the orientation to the demanding production of prime quality goods and a large degree of inno- 
vation is vital (Gibarti, 2009). Therefore, research is supported by law in the Czech Republic and Rene Wokoun (2008) suggests that National Research and Innovation Policy (NRIP) is the crucial document. Its goals include a productive research system of high quality, effective dispensing of knowledge and its utilisation in innovations, reinforcement of innovative power in the business sector and the establishment of a stable environment suited to carry out research (Czech Government Office, 2015). Moreover, Libor Kraus (2014) adds that NRIP also takes the national documents into account, for instance The National Innovation Strategy of the Czech Republic, The International Competitiveness Strategy for the Czech Republic for a period of 2014-2020, or National Priorities of Oriented Research, Experimental Development and Innovations. Just as in the period of 2007-2013, several operational programmes that are crucial from the point of view of research and development were approved in the Czech Republic for the following 2014-2020 period. The targeted support of science and research in the Czech Republic is perceptible but it remains questionable, what the level of higher education, or more precisely subsequent human capital/labour force that significantly influence the possibilities of science and research, is.

From the point of view of Jiri Winkler and Martin Žižlavský (2004), the structure of education of the workforce speaks most about the employment on the labour market. A transformation of Czech educational system has been launched after the Velvet Revolution with an aim to improve and reinforce the position of education due to the exponential information growth, profound changes in life-style, great impact of global influences on the economy, environment and people's health (Novotný, \& Zukerstein, 2011; Hlad'o, 2013). One of the top priorities has been to ensure that graduates gain the kind of knowledge that will help them to higher employability and better employment on the labour market which is rapidly changing.

According to Pavel Kuchař and Ladislav Vaska (2013), one of the causes giving rise to unemployment is the fact that the economy is being shifted in a certain direction, thereby exerting pressure on the labour force which subsequently has to adjust its knowledge and skills to the new requirements - something not everybody can manage. Anne E. Green and David Owen (2006) add to it that increased polarization between qualification requirements and qualification offers of the local labour markets is a typical feature of the current situation on the market.

The matter of employment pertains to the 15 areas of the EU priorities and resonates with a range of strategic documents such as the European Employment Strategy or a strategy for advancement called Europe 2020. Actually, modern Europe is having troubles with the high rate of unemployment of young population exceeding $20 \%$, temporary and part-time character of new jobs created for the young generation and the dissonance between their capacity and demands of the labour market. The employment of graduates is the priority also in the Czech Republic, which in 2010 approved some quantified national main goals and subgoals under the 
terms of the strategy Europe 2020. These include a reduction of the youth unemployment rate by a third compared to the same rate in 2010 (Vojtěch, \& Paterová, 2014).

An education of high quality that at the same time reflects the needs of the labour market is a means of reducing unemployment. In 2012, $17.3 \%$ of the young population in the Czech Republic received a university education, which is by 7.3 \% more than in 2000 (Czech Government Office, 2012). Despite the fact that the total number of university students in the Czech Republic in the period of 20001-2012 doubled and in case of graduates even tripled, the Czech Republic shows one of the lowest rates of tertiary educated population in the whole EU. According to Vladimir Kuchař a Zdenka Mindlová (2013), the aim of the EU is to increase the share of university graduates to $31 \%$ in 2010 and to $40 \%$ by 2020 .

The choice of future education is extremely important for many pupils and students. Sufficiency, comprehensibility and accessibility of information are fundamental to the successful selection. Petr Hlad'o (2013) claims that up to $60 \%$ of primary school pupils in the Czech Republic struggle with the choice of future education especially due to their indecisiveness. Pupils are in the so-called exploration stage, at which they often change their interests and have not yet formed definite priorities. The indecisiveness combined with a lack of popularity of subjects like maths, physics or chemistry manifests itself in primary and secondary school pupils' indifference towards natural sciences which has an unfavourable effect on the number of prospective students of these branches of science (Danielová, 2013). Nevertheless, people with a university degree from natural or technical fields of study are the most important for scientific and research activities (ČSÚ, 2007). As Anna Sandanusová and Radmila Dytrtová state (2010), continuous reduction of students of natural sciences and technical subjects compared to the number of students of other disciplines is a trend which is amplified by the fact that not many students are now about to enter universities due to a low birth-rate of certain years.

A number of institutions try to fight the potential students' lack of interest with various activities that belong to the so-called popularization of science (León, 2004; Sandanusová, \& Dytrtová, 2010), which makes an effort to bridge the gap between the communication of science and the society (Junior \& Orrico 2009). Therefore the principle of popularization lies in an entertaining grasp of scientific knowledge so as it is accessible to the general public. Alireza Noruzi (2008) defines the main aims as well. These include mainly awakening public interest in and knowledge about $S$ and $R$, a practical application of its results, support of cooperation and participation of public in the development within the science fields, and an integration of public into the popularization of solving scientific and research tasks.

The weak point of the popularization of science in the Czech Republic is also the focus of information that is presented to the experts but not to primary school pupils and the youth. Therefore, Juraj Ševčík, Michal Smolka 
and Pavel Vysloužil (2009) consider the primary school pupils to be the most important target group of science popularization because they are just starting to learn about their interests. The Czech Republic has only begun to employ successful foreign methods such as children's universities, public contests, educational stays, popularization centres etc. However, there are even examples of good projects and events that strive to engage pupils from primary and secondary schools in particular (for example Academia Film Olomouc, project Badatel, project Česká hlava, Week of Science and Technology, ENTER, Heuréka and so on) (Pokorná, 2009; Ševčík, Smolka, \& Vysloužil, 2009).

Sandusová and Dyrtová (2010) say that closer cooperation between teachers at primary and secondary schools with scientific institutions could help to solve the problem of a lack of interest in science. The willingness of teachers, headmasters and scientific workers themselves to join the popularization efforts is paramount. Teachers motivate pupils, headmasters can get grants to boost the cooperation and scientific workers encourage young researchers. One of the centres, which aim for the cooperation in the field of natural sciences, is the scientific educational centre of MU - Biskop. The presented contribution evaluates its activities within the context of attracting primary and secondary school pupils' attention to the natural sciences.

\section{DESCRIPTION OF THE SCIENTIFIC EDUCATION CENTRE (MU BRNO)}

The centre in question is relatively small and its establishment is connected to the project MU: Science and Scientists for the Education of Modern Society, which was implemented during the years 2012-2014. The project made an effort to popularize and promote the natural sciences, especially biology and chemistry (Masaryk University, 2014). The aims of the project, apart from the popularization of science and its accessibility to the general public, were additions to teaching at schools and the establishment of a centre that will develop talented students' potential. The motto of the centre declares that the meaning of Bioskop is to show that "science does not have to be rocket science" and it tries to entice the pupils to become science students. Thus, the centre endeavours to explain the social and economic reasons for the promotion of science and research, to supplement standard teaching at primary and secondary schools both materially and spatially and to create a base for qualification improvement of educators who teach natural sciences (Masaryk University, 2014). Therefore, Bioskop deals with a need to expose science to as many prospective applicants as possible and to create conditions suitable for a growth of the number of students studying and graduating from natural sciences.

Furthermore, the centre raised the wherewithal from European structural funds thanks to which it was able to organise programmes free of charge 
until the end of June 2015 under the project: Popularization of Science and Research in Natural Sciences and Mathematics Using the Potential of MU. This project also helped the centre to finally offer 20 courses for participants from different age groups - from six to seventeen years (Masaryk University, 2015). Since the centre opened in September 2013, the number of visitors in the courses counts up to thousands (visits can be repeated, though) (Bioskop, 2014). Nowadays, the courses are partially subjected to a fee, however, the turnout remains high and the centre still registers interest in its courses.

An important element of the running of the centre is collaboration. The centre drew inspiration from the organisation Vienna Open Lab, from which it adopted most of the courses (Bioskop, 2014). The centre tries to cooperate with other organisations that specialise in science popularization and promotion. The centre is in partnership for example with South Moravian Centre for International Mobility which supports influx of students and scientists into the region and at the same time encourages talented students from the South Moravian Region.

\section{METHODS}

The presented survey uses primary data because no similar research has been carried out before and therefore, there are no secondary data available. Written questionnaires have been chosen as a method for the evaluation of project Bioskop. Individual items were prepared on the basis of consultations with an activities coordinator from Bioskop. Moreover, feedback on the understanding of questions was provided and all the response options were assessed in regard to the accordance with the activities of the centre. The visitor's opinion collection took place from January 23, 2015 to April 23, 2015, altogether for three months.

The record sheets were distributed among the respondents both in an electronic way as online questionnaires, and physically on paper. Electronic questionnaires were available online. All the teachers who took part in one of the courses received an e-mail with a link to the questionnaire and were supposed to forward the information to their pupils. The links were sent out by the management of the centre Bioskop which has contact information about all the course participants at its disposal. Secondly, the link to the questionnaire was posted on the official website of the learning centre Bioskop. The paper questionnaires were graphically designed so that they motivated people to complete them. With the latter, in contrast to the online questionnaires, it was possible to paste the logo of Bioskop and to use an attractive colourful form. With this form of questionnaires, it was necessary to rely on respondents' attention because the utilisation of checking filter questions is limited.

The survey used a wide spectrum of different question types. Closed questions with one or more response choices were included, and free open questions that were supposed to determine what visitors found most inter- 
esting, or what should be improved as far as the courses are concerned. Furthermore, filter questions that divided the respondents into different groups based on their answers (questions related to the course turnout) and assessment scales for expressing one's opinion on the given scale were included, too. The content of the individual questionnaires varied in certain points because the target group consisted of primary and secondary school pupils and also their pedagogical escort. The introduction provided the respondents with an explanation of the reasons for the survey, the significance of their answers, then the way of filling out the questionnaire and respondent anonymity assurance. The questions about the attendance and attractiveness of the courses followed. And then also the questions aimed at subject preferences of pupils and students.

In total, 135 filled in record sheets were collected from primary and secondary school pupils, from which 73 were in the electronic form and 62 were paper questionnaires. 49 questionnaires were filled in by people who came with the children, out of which three had to be eliminated due to insufficient completion. Half of the record sheets were filled in online and half were printed questionnaires. During the primary processing of the outcomes, it turned out that the form of questionnaires did not have any influence on the collected data (there was no significant difference in the answers from the electronic and paper form of the survey). Smaller number of teacher respondents is logical because a teacher always escorts a larger group of pupils or students.

\section{RESULTS}

Research responders. It is difficult to evaluate the research realisation from the point of view of representativeness as exact sociodemographic statistics of the visitors of the courses are absent. Most of the teachers-responders were women $(87 \%)$. According to a statistical annual of Ministry of Education, Youth and Sports (MEYS, 2015) this percentage represents the share of female teachers at Czech elementary schools, which was $84 \%$ in the school year $2013 / 2014$. More than $3 / 4$ of teachers who took part in these courses worked at elementary schools. The percentage share of the number of teachers from elementary and secondary schools (including grammar schools) in this research equals to the share of the teachers at primary and secondary schools within the Czech Republic who participated in the courses of the evaluated centre (MEYS, 2015). It can be said that elementary school pupils are far more formative and such forms of education can persuade them of the fact that school can also be enjoyable. Elementary school pupils also have more free time, teachers have better possibilities to show the pupils something new, that can make them more interested in science. Considering the above mentioned facts it is not surprising that the majority of answers were acquired from elementary school pupils and students (57\%). Grammar school students comprise $3 / 4$ of secondary school students who participated in this research. 
Most of the education institutions, stated by the research responders, are situated in the South Moravian region which points to the regional field of action of the centre, attracting visitors from the South Moravian region. A dominant group is formed by Institutions situated in the county Brno-město (Brno-city, TN) where the scientific centre Bioskop is located. The second and third most numerous groups (2/5 of the visitors) are responders from counties Brno-venkov (Brno-country, TN) and Znojmo. It is very probable that teachers also find the distance between their school and the scientific centre very important. Longer distances may result in higher expenses as well as longer time consumption. Moreover, teachers cannot free their pupils from the education process for such a long period.

The centre was sought mainly by science teachers (59\%) as the centre focuses on this field of study. Teachers of humanities (15\%) participate in the courses for various reasons. Some are the class masters and want to make the education process more colourful for their pupils, some are "only" substitute supervisors of another teacher.

Regarding the share of individual grades of education institutions, grade 8 (a half of the students) and grade 9 students participated with the highest frequency. Grade 1 and 3 of secondary schools responders participated equally. The research results showed that the responders had participated in their first course of the evaluated centre. The results also showed that those responders who had participated in more courses visit the centre regularly from 2014 and are elementary school pupils.

Assessment of the evaluated centre. The overall assessment of courses done by pupils and students show that the courses were evaluated very positively (As and Bs were most frequent). The course gained the best evaluations for its practical and instructional nature. The responders' answers show that the possibility to find out how things work and the chance to learn new and interesting facts was what they enjoyed the most. The quality of the centre is obvious also from the point of view of human capital as several responders positively evaluated the quality of lecturers' explanations, often evaluated as absorbing and comprehensible. Only less than one third of responders assessed some of the evaluated course characteristics with the two worst grades (D and E), mostly for the course being too theoretical.

The quality of the centre is positively perceived also by the second group of responders - teachers. They stated that most students (76 \%) were excited by the course and would like to visit it once more. The teachers-responders received positive reactions also from parents who were informed of the course by their children. All the above mentioned facts prove good position and competitiveness of the centre, as 3/4 of teachers, who have experience from other similar centres financed also from operation programmes (59\% of the responders had such experience), gave Bioskop centre the best grade compared to others. Even more teachers (74 \%), who have experience with an education centre focusing on science, gave Bioskop centre a very good grade. More than a half of them gave the centre 
and its activities, compared to other centres focusing on science, the best evaluation.

The quality and attractiveness of the centre can also be assessed based on the participants' motivation to take part in another course. $86 \%$ of pupil and student responders stated they would like to do so. This group was motivated mainly due to a fact that they learned new things during the course and enjoyed the course very much (62\% of responders). The possibility to practically try experiments was motivating for $53 \%$ of responders.

Secondary school students, compared to elementary school students, evaluated the education and fun within the courses more positively. For example, none of the secondary school students assessed any of the course aspects with a grade E. The practical experiments and exercises, however, were enjoyed more by elementary school students (39\% of them stated in the related open question). Generally, according to an OECD study (2008) younger students enjoy practical experiments and learning via experiments more. Secondary school students enjoy specific experiments, such as DNA and RNA testing, experiments with cells and bacteria, paternity tests. Here, this is connected with the evaluation of the course with respect to its instructionality. If students feel that the subject matter is reflected in practice, they are more motivated and interested in the following knowledge, including theory.

\section{I would like to focus on the fields of natural science (biology, chemistry, botany, genetics, ecology, etc.) in the future}

I liked the enthusiasm of course instructor

I liked that we did practical experiments

I enjoyed the course

I learned a new things

Another course can help me to find an appropriate educational institution in the future

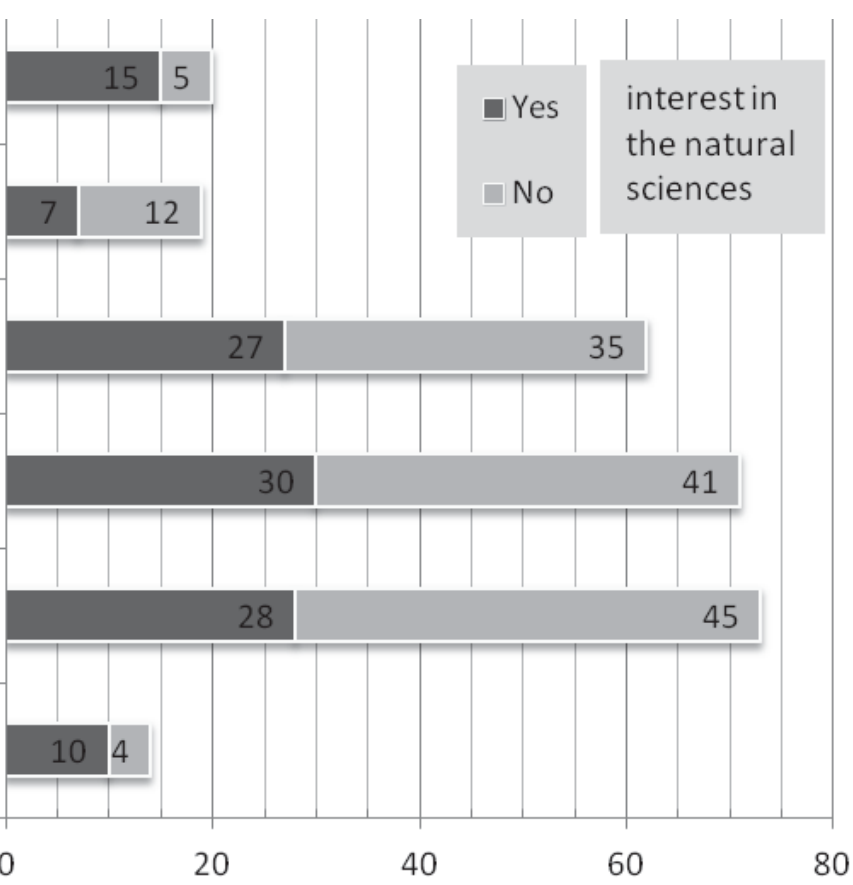

Fig. 1. The significance of pupils' and students' factors of motivation to participate in another course of the centre according their interest in natural sciences. Note: in this question the respondents were offered to mark any number of answers. On average, every second pupil marked at least two factors of motivation to participate in another course. 
The students' answers proved that the teachers' motivation to participate in the course with their pupils and students was fulfilled. Two thirds of the teachers in the research stated that the main motivation for them to visit the centre was:

- interesting topics,

- aim to show and introduce science to their students,

- make the students realise the importance of this form of education and

- the need for more diverse forms of education.

Motivating university environment together with a modern lab and high quality equipment was assessed as the strongest point of the centre. The teachers also emphasised the process and character of the course, i.e. its balance, instructiveness, fun, flexibility and comprehensibility. They also appreciated the contact with a young team of lecturers (students) who may motivate the pupils and become friends with them. Teachers also positively evaluated the possibility to actively participate in practical experiments, the amount of safety equipment (cloak, etc.) which make the students feel like "real researchers". $76 \%$ of participating teachers stated that the scientific centre Bioskop does not need any improvements and only $3 \%$ of teachers think that the centre has no strong point.

Students' field preferences. Apart from the feedback on the quality and attractiveness of the centre, the main aim of the research was to find out whether the courses may help to attract students to continue in science studies. The results showing the above mentioned strength of the individual motivations for another visit of the centre reveal that the least motivating ( $12 \%$ of the answers) was the interest in nature or a belief that the course may help pupils and students find or choose their future study. On the other hand, teachers participating in the research think that the scientific education centre Bioskop brings benefits also in this area. $87 \%$ of teachers consider the courses as an excellent way of broadening students' horizons in the field of science, and $74 \%$ of teachers think that the centre is capable of making science attractive. One of the reasons for these expectations may be a fact that the centre offers pupils and students a possibility to experience and try something interesting and the same time educative, which cannot be realised within the elementary and secondary schools (4/5 of teachers). Despite this only $39 \%$ of teachers think that the scientific centre Bioskop may help students decide about their future studies.

Pupils' and students' answers showed that they are mainly interested in technical science (44\% of answers), followed by natural science (34\%). Students were least interested in humanities. Boys, elementary school students and grade 8 students showed the biggest interest in technical science $74 \%$ of elementary school students). On the contrary, girls, secondary school students, mainly grade 3 students (77 \%) inclined to natural science. Here it has to be noted that these grades (together with grade 4 secondary school students and grade 9 elementary school students) are the most important when deciding whether the students will continue with science or not (OECD, 2008). 


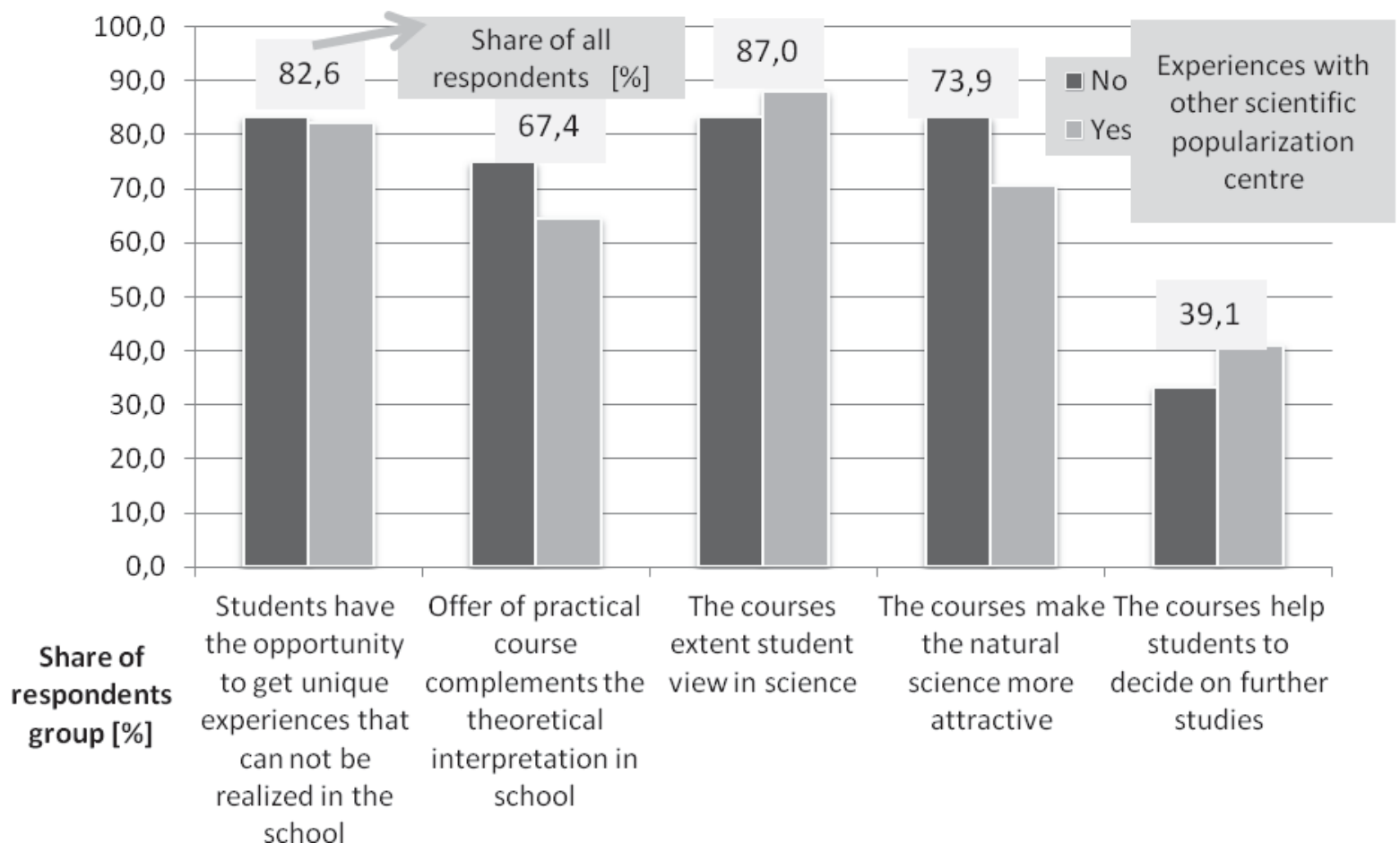

Fig. 2. The benefit of education centre Bioskop from teachers' point of view according their experiences with other courses of natural science popularization centres. Responders could choose more than 1 answer.

For example, grade 9 elementary school students in this phase of development should set their priorities when choosing their future field of study. Grade 1 secondary school students, on the other hand, express their decision on which way they want to continue (Hlad'o, 2013). For example, some secondary school student responders studied at Secondary vocational school of food technology and chemistry which obviously shows their interest in natural science. $92 \%$ of this vocational school students expressed interest in natural science.

Analysis of the preferences of specific fields which are covered by the centre shows that elementary school students prefer fields such as zoology, geography, physics or chemistry. Secondary school students prefer medicine, chemistry, general biology and physics (Fig. 3). If the responders selected other (not-defined) fields, most frequently they stated technical fields such as information technologies, graphics or engineering. The second most frequent field of study was humanities (history, art and singing, literature and languages) followed by social studies (economics, sociology, psychology, journalism). The least frequent fields of study within the not-defined category included mathematics, biochemistry, genetics or physiotherapy. These results are logical considering the fact that most respondents selected the fields of study from the defined possibilities. 


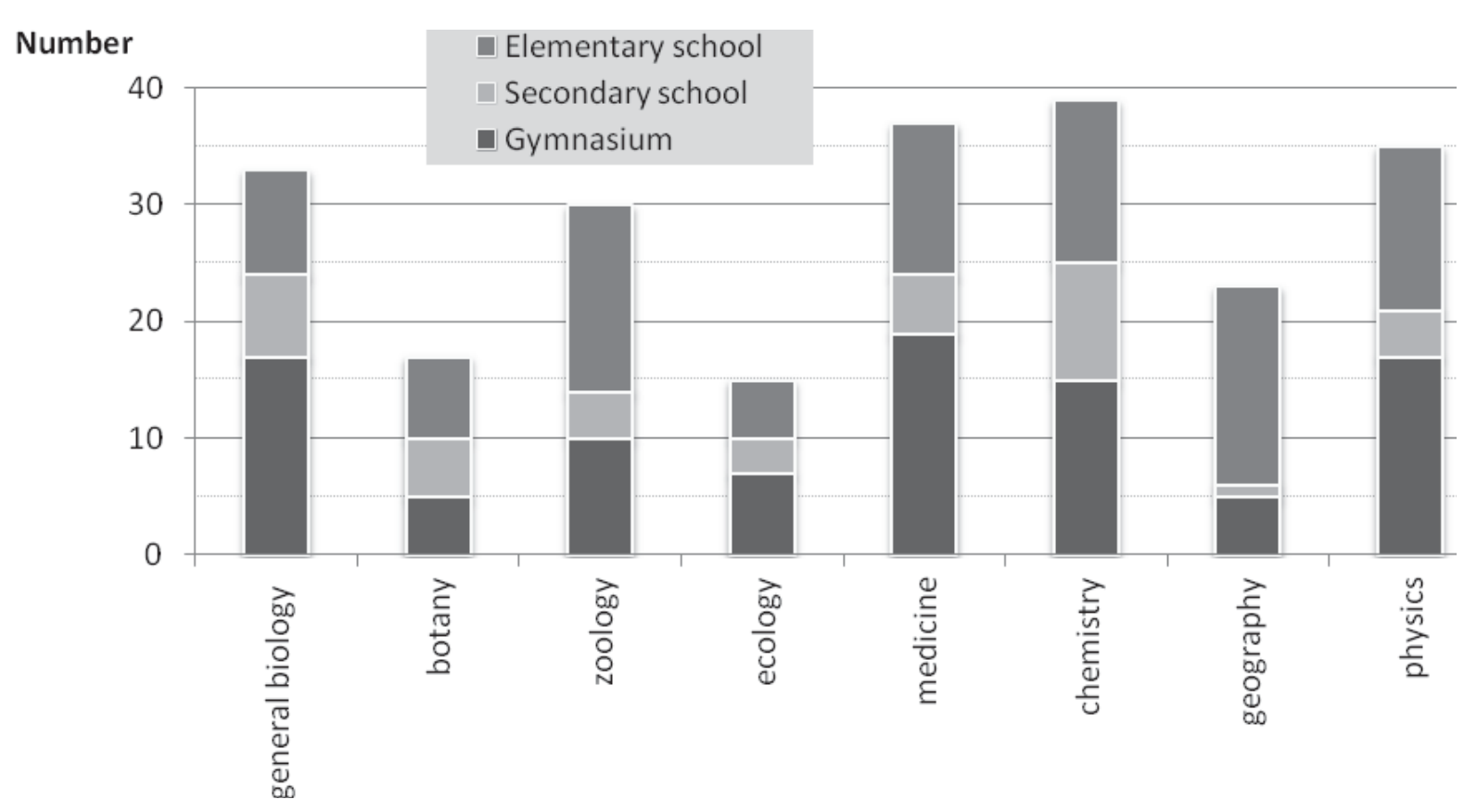

Fig. 3. The structure of pupils' and students' fields of interest. Note: this question also gave the possibility to select more answers (or none) or fill in own answer.

The results allow us to say that no significant ambiguity of science classification within its fields and areas has been recorded. The results demonstrated that those pupils and students who had not considered selecting a scientific field before they participated in the course stated these fields as preferred and their motivation for participating in another course again was very high. Therefore it can be stated that these $60 \%$ of students were impressed by the course and science itself. Before the course $40 \%$ of students stated that they are interested in science. This group was very motivated to participate in another course in the future.

Despite the above mentioned findings on the significance of the centre and positive evaluations, the question is how to motivate parents to understand the importance of such activities from the point of view of the future professional lives of their children. The research showed that $4 / 5$ of the teachers think that parents would be willing to pay CZK 1-100 for the course. As the financial support of the centre from the European funds stopped in June 2015 (together with free courses), the challenge now is how to make the centre run without these external sources. This scientific centre, together with other similar centres, faces a problem of how to make parents understand that such courses are not only fun, but improve their children's knowledge and help them decide about their future professional life. 


\section{CONCLUSION}

The research among primary and secondary school students and their teachers who visited at least one course of scientific education centre Bioskop Masaryk University showed positive evaluations and inconsistent attitudes on how to make science more attractive for young population. Almost 90 $\%$ of all pupils and students expressed their interest to visit more courses, mainly due to a fact that the course offered them learning about new things and trying practical experiments in a scientific laboratory. 3 times less students were motivated by the fact that students were aware of their interest in science or of the fact that the centre can help them select a suitable education institution for their future studies and professional development. The fact is that during its 3-year-long operation the centre has attracted many visitors from elementary and secondary schools. Even if they are not motivated by selecting a scientific field, meeting science may influence them in their future decisions.

This assumption is proved by the research results showing that teachers positively evaluated areas such as instructionality, practicality and fun of the courses. Teachers' motivation to visit the course included interesting topics, colourful education processes and the possibility to show their students what natural science can offer. The results demonstrate that these courses may broaden students' horizons in the field of science and show them things they cannot see at school. However, the centre Bioskop is not capable of attracting more students to study science, the centres have no influence on science popularisation. The main aim of these courses - make the science attractive and demonstrate "the world of science" - is fulfilled and centres help students realise whether science and research are attractive for them.

Pupils and students stated that they are interested in technical and natural sciences. Secondary school students are interested in specific fields (e.g. biochemistry or genetics). The question is how much were students influenced by the courses when they selected these fields of interest. If at least some of the students remain interested in technical and natural sciences, popularisation activities of the assessed centre will be responsible for new applicants for these fields at universities. Therefore it is obvious that the problem of the centre is not its meaningfulness, but its long-term sustainability. The courses cannot be free any more, due to termination of financial support of the centre from structural funds, however parents and other decision makers are only sporadically aware of the importance of the popularisation activities.

\section{ACKNOWLEDGMENT}

The article was supported as non-project research of Mendel University in Brno and IGA FRDIS (13/2015). 


\section{REFERENCES}

[1] Bioskop (2014). Výroční zpráva září 2013 - srpen 2014 [Annual report September 2013 August 2014]. Retrieved from http://bioskop.muni.cz/media/1681625/bioskop-vyrocni-zprava-2014.pdf.

[2] Czech Government Office (2012). Analýza stavu výzkumu, vývoje a inovací v české republice a jejich srovnáni se zahraničím v roce 2012 [Analysis of the state of research, development and innovation in the Czech Republic and their comparison with foreign countries in 2012]. Prague: Czech Government Office.

[3] Czech Government Office (2015). Národní politika výzkumu, vývoje a inovací České republiky na léta 2016 - 2020 [National policy of research, development and innovation in the Czech Republic for the years 2016 - 2020]. Prague: Czech Government Office.

[4] Czech Statistical Office (2007). Věda a výzkum v regionálním pohledu [Science and research in regional perspective]. Prague: Czech Statistical Office.

[5] Danielová, L. (2013). Vybrané trendy celoživotního učení v České republice a dalších státech Evropské unie [Selected trends of lifelong learning in the Czech Republic and other EU countries]. Brno: Mendel University in Brno.

[6] Gibarti, J. (2009). Inovační prostředí regionů České republiky [Innovative environment of the regions of the Czech Republic]. Prague: Josef Hlávka Economics Institute.

[7] Green, A. E., \& Owen, D. (2006). The geography of poor skills and access to work. York: Joseph Rowntree Foundation.

[8] Hlad'o, P. (2013). Rozhodování žákư absolventských ročníků základních škol o další vzdě-lávací a profesní dráze: analýza na základě dotaznikového šetření a ohniskových skupin [Deciding graduate students of elementary schools for further education and careers: analysis based on the survey and focus groups]. Brno: Mendel University in Brno.

[9] Hlaváčková, T. (2015): Význam vědeckého výukového centra MU - Bioskop pohledem učitelů ZŠ a SŠ [The importance of scientific education center MU - Bioskop glance primary and secondary school]. Retrieved fromhttps://is.mendelu.cz/lide/clovek.pl?id=32938;zaloz $\mathrm{ka}=13 ;$ studium $=65901 ; \mathrm{zp}=50867$;lang $=\mathrm{cz}$.

[10] Junior, L., S., \& A., Orrico, E. (2009). Information Science, Popularization of Science and Social Memory: Dialog with Knowledge Organization. In: Congress Isko-Spain: New perspectives for the organisation and dissemination of knowledge (pp. 506-521). Valencia: International Society for Knowledge Organization.

[11] Kraus, L. (2014). Mezinárodní projekty v oblasti VaV [International R \& D projects]. Ostrava: VSB - Technical University of Ostrava.

[12] Kuchař, P., \& Vaska, L. (2013). Regional aspects of unemployment in the Czech Republic and Slovakia. Ústí nad Labem: Jan Evangelista Purkyně University.

[13] Kuchař, V., \& Mindlová, Z. (2015). Uplatnění absolventio prírodovědných a technických oborù. Generace $Y$ [Application of science and engineering disciplines. generation $Y$ ]. Retrieved from http://www.generacey.cz/uploads/ke_stazeni/Reserse_uplatneni_absolventu.pdf.

[14] León, B. (2004). Science popularisation through television documentary: A study of the work of British wildlife filmmaker David Attenborough. Retrieved from http://www.pantaneto.co.uk/ issue15/leon.htm.

[15] Masaryk University (2015). Výukové centrum Bioskop nabízí program na jarní prázdniny [Bioskop Learning Center offers a program for Spring Break]. Retrieved from http://bioskop. muni.cz/media/1681626/tz_bioskop-8-1-2015-jarni-prazdniny-fin.pdf.

[16] Masaryk University (2015). Zajímá vás, co dělají vědci? Objevte fascinující svět vědy: výroční zpráva [Wondering what scientists do? Discover the fascinating world of science: annual report]. Retrieved from http:// bioskop.muni.cz/media/1681625/ bioskop-vyrocni-zprava-2014.pdf.

[17] Ministry of Education, Youth and Sports (2015). Statistická ročenka školství - výkonové ukazatele [Statistical Yearbook of Education - Performance Indicators]. Prague: Ministry of Education, Youth and Sports.

[18] Noruzi, A. (2008). Science Popularization through Open Access. Retrieved from http://www. webology.org/2008/v5n1/editorial15.html.

[19] Novotný, J., \& Zukerstein, J. (2011). Současné trendy v oblasti popularizace technického vzdělávání na základních, středních a vysokých školách [Current trends in popularizing technical educa- 
tion at primary, secondary and high schools]. Ústí nad Labem: Jan Evangelista Purkyně University.

[20] Pearce, D., W. (1993). Macmillani̊v slovník moderní ekonomie [Macmillan Dictionary of Modern Economics]. Prague: Victoria Publishing.

[21] Podhorná, A. (2015): Hodnocení projektu Bioskop pohledem žáků ZŠ a SŠ [Evaluation of the project Bioskop view of primary school pupils and secondary school students]. Retrieved from http:/ /is.mendelu.cz/lide/clovek.pl?id=32938;zalozka=13;studium=65981.

[22] Pokorná, G. (2009). Nové, moderni nástroje popularizace výsledki̊ vědy, výzkumu a vývoje na vysokých školách v ČR [New, modern tools popularization of scientific, research and development at universities in the Czech Republic]. Olomouc: Palacký University Olomouc.

[23] Powell, W., \& Snellman, K. (2004). The Knowledge Economy. Annual Review of Sociology, 30, 199-220.

[24] Sandanusová, A., \& Dytrtová, R. (2010). Popularization of science and research in the education. Brno: Tribun EU.

[25] Ševčík, J., Smolka, M., \& Vysloužil, P. (2009). Manuál popularizace a medializace vědy [Manual of popularization and media promotion of science]. Olomouc: Palacký University Olomouc.

[26] Vavrečková, J. (2007). Postaveni védy a výzkumu v ČR; riziko odchodu vědcü, výzkumných a vývojových pracovníkù z ČR do zahraničí: souhrnná studie [Position of science and research in the Czech Republic; the risk of leaving scientists, researchers and developers from the Czech Republic to abroad: comprehensive study]. Prague: Research Institute for Labour and Social Affairs.

[27] Vojtěch, J., \& Paterová, P. (2014). Vývoj vzdělanostní a oborové struktury žáků a studentů ve středním a vyšším odborném vzdělávání v ČR a v krajích ČR a postavení mladých lidí na trhu práce ve srovnání se stavem v EU - 2013/14 [The development of educational and sectoral structure of pupils and students in secondary and higher vocational education in the Czech Republic and Czech regions and the status of young people in the labor market compared with the EU 2013/14]. Prague: National Institute for Education.

[28] Winkler, J., \& Žižlavský, M. (2004). Český trh práce a Evropská strategie zaměstnanosti [Czech labor market and the European Employment Strategy]. Brno: Masaryk University.

[29] Wokoun, R. (Ed.). (2008). Regionální rozvoj: (východiska regionálního rozvoje, regionální politika, teorie, strategie a programování) [Regional development (knowledge base of regional development, regional policy, theory, strategy and programming)]. Prague: Linde. 